\title{
Analysis of village owned enterprises (BUMDes) financial performance before and during COVID-19 pandemic
}

\author{
Raida Fuadi $^{1 *}$ Linda $^{1}$, Gamal Batara ${ }^{1}$, Nurma Sari ${ }^{2}$ \\ ${ }^{1}$ Accounting Department, Universitas Syiah Kuala, Banda Aceh, Indonesia \\ ${ }^{2}$ Islamic Economic Department, Universitas Syiah Kuala, Banda Aceh, Indonesia
}

\begin{abstract}
COVID-19 outbreak had brought a significant impact on economic dynamics in Indonesia, including rural economy. Rural economy continues to decline which is marked by an increase in the poverty rate and a decrease in the purchasing power of rural communities. This study aims to analyse BUMDes financial performance before and during COVID-19 pandemic in Banda Aceh city. BUMDes or Viilageowned Enterprises are village business institutions managed by village's community and village's government in order to strengthen the village economy based on needs and potential of the village. The indicators of financial performance used in this study are sales and the ability of BUMDes to pay their debts. This study uses primary data. The population are managers of BUMDes located in Banda Aceh city. The sampling method used in this study is random sampling. Analysis of differential test between BUMDes financial performance before and during COVID-19 pandemic is performed using paired sample t-test. The financial performance variables are sales turnover and liquidity. BUMDes sales turnover is measured by the number of sales, while BUMDes liquidity is measured by BUMDes ability to pay salaries and also BUMDes ability to pay operational debts. The results show that there is a significant difference between the number of sales before COVID-19 pandemic and the number of sales during COVID-19 pandemic. The descriptive statistics shows that the average sales before COVID-19 was higher than the average sales during COVID19 pandemic. This significant difference is indicated by a $\mathrm{p}$-value $<0.05$, which is 0.05 . Meanwhile, BUMDes ability to pay its employees' salaries and BUMDes ability to pay debts are not significant, because the p-values $>0.05$, which are 0.83 and 0.25 respectively. The descriptive statistics shows that the average BUMDes ability to pay debts before COVID-19 pandemic was higher than the average ability to pay debts during COVID-19 pandemic.
\end{abstract}

\section{Introduction}

Indonesia government since 2015 has distributed extra amount of money and authority to villages around Indonesia. The goal is to support villages so that they are able to manage their potentials to improve rural economy as well as the welfare of rural communities. Villages economics are the foundation of country economics development, therefore Indonesia government delegates fund management authority to villages, so that villages are able to manage their own economic potential through BUMDes (Village-owned enterprises). BUMDes accommodates the economic activities of rural community in a form of business entity that is managed professionally. The main business activities of $B U M D e s$ however still rely on the original potential of the village. This hopefully will bring benefits for rural communities by making community businesses more productive and effective.

Aceh is the second province with the most BUMDes in Indonesia, with 7,831 BUMDes. The first region is East Java with 8,035 BUMDes [1].

According to the Head of Village and Community Office (DPMD) (2018), the problem in Aceh is that the number of poor people in Aceh continues to increase while village funds transferred by central government are also increasing every year. Data obtained from the Village and Community Empowerment Office (DPMD) of Banda Aceh, currently there are 28 active BUMDes and 62 inactive BUMDes in Banda Aceh. DPMD Office needs to conduct an evaluation of 2018 programs and socialize their next programs in for 2019, to prevent other BUMDes bankruptcy. BUMDes should be able to become a platform for economic empowerment of the poor community. Thus, BUMDes should be assisted and monitored so that they get a clear direction. Their performances should also be assessed, to identify how far BUMDes could bring benefit to the community by increasing sales, so that they can bring welfare to their workers and also to the local community [2].

While Aceh government had not been able to maximize the performance of BUMDes, COVID-19 outbreak started in mid-2020. As a result of the COVID19 pandemic, some fearful predictions have emerged from business actors. This is because the increasing amount of budget for health care sector. This pandemic has brought social and political uncertainty to countries around the world and has an impact on the global economic crisis. According to [3], policy makers have

\footnotetext{
${ }^{*}$ Corresponding author: lindarisyad@unsyiah.ac.id
} 
to make an analysis of economic predictions due to the effects of COVID-19 because the economic crisis has emerged and progressed very quickly. Business actors need to conduct surveys that can assess future steps in the midst of this uncertainty. The founder of the great ecommerce, Alibaba, Jack Ma, said that 2020 is the year of survival, while 2021 will be the recovery year for business to start gaining profit again.

Village fund is allocated from Indonesia State Budget (APBN). This village fund is directly transferred by the central government to the village account. One of the allocations is for village's BUMDes activities. However, since the COVID-19 outbreak, the allocation has changed significantly, due to the urgency for healthcare allocation. Based on the [4], the minimum allocation of village funds for COVID-19 is $8 \%$, while for the maximum amount is not limited.

With the increasing allocation for COVID-19 healthcare, the allocations for other posts are decreased, including allocation for BUMDes activities. On the other hand, BUMDes are expected to trigger and drive the village economy in the midst of economic downturn during COVID-19 pandemic. The results of research by [5] shows that most of the micro, small and mediumsized enterprises in Pakistan are facing financial problems, supply chain cycle disruptions, demand declines, sales declines and profit declines during this COVID-19 pandemic. $83 \%$ of companies reported that they were not prepared to handle the situation and that they had not planned their next steps to face the pandemic.

[6] conducted a qualitative research on BUMDes in Wiau Village, Southeast Minahasa Regency, Indonesia. The research uses an approach proposed by George Terry regarding management functions, such as planning, implementation, and supervision. From the planning function, there have been changes in BUMDes revenue target. Previously, the village's BUMDes income streams are from savings and loans business and also from equipment rental used for traditional community events. The revenue target was extended from the previous target and even removed from the target. In terms of program implementation during the COVID-19 pandemic, they still rely on the type of business that is still in accordance with the regulations. The financial report shows a decrease in BUMDes income due to small scale of activities during COVID19 pandemic.

On the other hand, there is a village that could adapt and survive during COVID-19 pandemic. A qualitative research by [7] on BUMDes in Sukorejo village concluded that during the COVID-19 pandemic, the economic performance in the village did not experience an economic downturn. During the pandemic, Sukorejo village optimizes the potential of its local strengths, both from social capital and economic capital. One of the village's capitals is agriculture. In addition, the Sukorejo village entrepreneurship strategy is able to stimulate BUMDes to develop a business strategy in the midst of COVID-19 pandemic. Economic activities in a situation of "physical distancing and lock down" only change the way or method of approaching BUMDes business.
From the discussion above, this study aims to analyse the financial performance of BUMDes before and during COVID-19 pandemic in Banda Aceh. Banda Aceh is the capital city of Aceh Province and Aceh Province is one of the provinces in Indonesia that receives the largest village funds in Sumatera due to its large number of BUMDes [8].

\section{Literature review}

\subsection{Economics uring COVID-19 pandemic}

The current COVID-19 pandemic is having a bad impact on the Indonesian economy. The Organization for Economic Co-operation and Development (OECD) reports that the COVID-19 pandemic has resulted in the threat of a major economic crisis marked by the cessation of production activities in many countries, falling levels of public consumption, loss of consumer confidence, and falling stock exchanges that ultimately lead to uncertainty [9]. In the release of Indonesia's economic growth in the first quarter of 2020 issued by the Central Statistics Agency (BPS), it is clear that the COVID-19 Pandemic has caused damage to the Indonesian economy. The growth rate for Indonesia's Gross Domestic Product (GDP) in Q1 2020 was recorded at only $2.97 \%$ (year-on-year). This figure is the lowest growth rate since 2001. The Ministry of Finance and Bank Indonesia previously had predicted growth in the range of $4 \%-5 \%$ in Q1 2020. The GDP growth during COVID-19 was much lower than predicted. On the expenditure side, the biggest contraction in GDP was recorded in household consumption expenditure, which worsened by $2.84 \%$, representing the largest contraction in consumption since 1999.

The sharp decline in consumer household spending can be attributed to at least two things. First, it is caused by an increase in the number of unemployed, which directly impacts decreasing income and household consumption expenditure. Second, it is caused by an increase in uncertainty due to the COVID-19 pandemic. This increased uncertainty has led to a shift in consumption to precautionary savings by households whose income has not been greatly affected by this pandemic. However, not all sectors in the economy have heterogeneous impacts. According to [10], some of the sectors severely affected were the transportation sector $(1.27 \%$ from the previous $7.55 \%)$, the construction sector $(-2.41 \%)$, and the manufacturing industry ($1.47 \%)$. Various innovations that are more directed at the defence of people's welfare are needed during the COVID-19 pandemic because, in the end, the people's purchasing power is better able to help the economy move and save business growth, business profitability, and national economic growth [11].

\subsection{BUMDes sales during COVID-19 pandemic}

The economic impact of COVID-19 can emerge a major economic crisis. This is indicated by a decreasing production activities, decreasing people's purchasing power, falling stock market, which leads to uncertainty 
[12]. During the COVID-19 pandemic, MSMEs are also affected by this pandemic. The Minister of Cooperatives and MSMEs, Teten Masduki, stated that based on the results of a survey, COVID-19 pandemic has a major impact on the sustainability of MSMEs [13]. 47 percent of MSMEs had to go out of business due to the impact of the COVID-19 pandemic. The sustainability of MSMEs is also affected by this pandemic. MSMEs are experiencing cash flow health problems and weakening on the demand side which suppresses the sustainability of MSMEs.

During the monetary crisis, net income decreased significantly due to weakening people's purchasing power and increased interest costs, so that a firm's profitability decreased significantly. When people's purchasing power decreases, it will certainly impact the company's total sales. When the company's sales decline, its profit will also decrease if the company is unable to minimize operating costs incurred. The results of [14] show that the profitability ratio, measured using returns on assets (ROA), of service companies before the monetary crisis and during the monetary crisis differ significantly, where there is a decrease in the average ratio. [15] also states that there was a decline in public companies' financial performance on the Jakarta Stock Exchange for all sectors during the crisis, especially at the level of ability to generate profits, as indicated by a significant decrease in ROA. In addition, [16] show that the COVID-19 pandemic has a significant negative impact on listed Chinese companies' performance due to a decrease in the value of total revenue, which has impact on reducing ROA. Thus, the first hypothesis can be formulated as follows:

H1: There is a difference between BUMDes sales before and during the COVID-19 pandemic

\subsection{BUMDes ability to pay debts during COVID- 19 pandemic}

World Bank Managing Director, Mari Elka Pangestu, estimated that Indonesia's economic growth could weaken below $5 \%$ in the first quarter of 2020 [17]. The financial performance of the industrial sector will also certainly be affected by the economic crisis [18]. This economic crisis will certainly lead to a decline in industrial sector sales due to decreased purchasing power [19]. If sales in the industrial sector experienced a decrease during the economic crisis due to the COVID-19 pandemic, this would certainly affect the company's financial condition in general, including the value of the company's current assets. The components of current assets that are significantly affected by sales changes are the cash component resulting from cash sales and the value of trade receivables as a result of credit sales. When current assets experience significant changes, this will ultimately affect the value of the current ratio. [20] show differences in financial performance, including the current ratio in the period before and after the monetary crisis. The result of [14] also shows that there was a significant decrease in a firm's liquidity ratios, measured using the current ratio, during the monetary crisis. Therefore, the second hypothesis can be formulated as follows.

\section{H2: There is a difference between BUMDes ability to pay debts before and during COVID- 19}

\subsection{BUMDes ability to pay salaries during COVID-19 pandemic}

In addition to the ability of BUMDes to pay operational debt, this study will also look at BUMDes ability to pay salaries as an indicator of BUMDes liquidity. [21] in his qualitative research concluded that the MSMEs had experienced problems in paying the salaries of their employees during the COVID-19 pandemic. This happened because at that time there was no income due to the absence of demand from consumers. In order to reduce their operational expenses, the MSMEs postponed the payment of employee salaries temporarily for one month.

Similar to the indicator of the ability to pay operational debt, the ability to pay salary expenses also experienced differences between before and during COVID-19. Therefore, the third hypothesis is formulated as follows.

H3: There is a difference between BUMDes ability to pay salaries before and during COVID-19 pandemic

\section{Research methods}

This study analyses the financial performance of $B U M D e s$ that were active in Banda Aceh before the time of COVID-19 outbreak. The financial performance indicators in this study are sales and liquidity. The data used in this study is primary data, using Likert scale, and in the form of cross section.

The sales variable refers to the research of Rofiqoh [15] and Pakpahan [12] the liquidity variable refers to the research of Istiningrum [14] and Sari [21].

Sales variable was measured using primary data by distributing questionnaires to respondents whereas measured using a Likert scale ratio. Questionnaire questions are a description of the total sales of BUMDes 19 and how consumer demand before the Covid pandemic was for goods and services sold by BUMDes. The liquidity variable also uses secondary data, using the Likert Scale. The liquidity variable in the questionnaire distributed to respondents is to measure the extent to which BUMDes can pay off trade debts and pay off workers' salary debts before the time of the covid 19 pandemics.

The population are the Head, Treasurer, and Secretary of BUMDes with total of 84 respondents. Sampling method used in this study is simple random sampling, using the Slovin formula:

$$
n=\frac{N}{1+N e^{2}}
$$

$\mathrm{n} \quad=$ sample size

$\mathrm{N}=$ population size

$\mathrm{e}^{2} \quad=$ margin of error $(5 \%)$

The population in this study is shown in Table 3 
Table 3. Population of BUMDes in Banda Aceh.

\begin{tabular}{|c|l|l|}
\hline No & \multicolumn{1}{|c|}{ Village } & \multicolumn{1}{c|}{ BUMDes Name } \\
\hline 1 & Ateuk Jawo & Atra Gampong \\
\hline 2 & Ateuk Deah Tanoh & BUMG Ateuk Deah Tanoh \\
\hline 3 & Peunayong & Hareukat Anak Naggroe \\
\hline 4 & Laksana & Mandiri \\
\hline 5 & Keuramat & Keuramat Jaya \\
\hline 6 & Beurawe & Hareukat Bersama \\
\hline 7 & Kuta Alam & Meukuta Alam \\
\hline 8 & Bandar Baru & Beru Beurukat \\
\hline 9 & Lampulo & Jroh Naguna \\
\hline 10 & Lambaro Skep & Semangat Baru \\
\hline 11 & Cot Lam Keuh & Ceko \\
\hline 12 & Gampong Baro & Desa Baro \\
\hline 13 & Punge Ujung & Punge Ujung \\
\hline 14 & Tibang & Tibang Makmu \\
\hline 15 & Deah Raya & Beu Sejahtera \\
\hline 16 & Panteriek & Meuligo Intan \\
\hline 17 & Blang Cut & Makmue Sejahtera \\
\hline 18 & Lampaloh & Sejahtera Bersama \\
\hline 19 & Geucu Inem & Cemerlang \\
\hline 20 & Lhong Raya & BUMG Lhong Raya \\
\hline 21 & Peunyerat & Hudep Saree \\
\hline 22 & Lhong Cut & Sejahtera \\
\hline 23 & Lamjamee & Lamjamee Mandiri \\
\hline 24 & Lampoh Daya & Lampoh Daya \\
\hline 25 & Emperom & BUMG Emperom \\
\hline 26 & Geuce Menara & Kembang Perdana \\
\hline 27 & Doy & Ade Beurata \\
\hline 28 & Ie Masen Ulee & Al Hidayat \\
\hline & Kareng & \\
\hline
\end{tabular}

Each BUMDes is represented by 3 respondents, thus the total respondents are 84 . Based on Slovin equation, minimum number of samples in this study is 45 respondents.

The data analysis uses paired sample t-test difference test. Paired Sample T-Test is a test used to compare the difference between two means of two paired samples with the assumption that the data are normally distributed. Paired samples come from the same subject, each variable is taken in different situations and circumstances. Before carrying out the Paired sample $t$ test, the data normality test must be first carried out, because the paired sample t-test is a parametric test.

The questionnaire in this study is also tested for validity and reliability. Validity shows the accuracy or level of accuracy of the measuring instrument. Reliability test is conducted to measure the consistency of measuring instrument in measuring respondent's consistency in answering question items in questionnaires or research instruments [22].

\section{Result}

\subsection{Respondents}

We sent questionnaires to 84 individuals. However, there are only 54 respondents that fully fill the questionnaires. The number of samples still meet the minimum number of samples based on Slovin equation which is 45 samples. The respondents. include the
Heads, Secretaries, and Treasurers of BUMDes in Banda Aceh city. Respondents come from various backgrounds with details shown in Table 1.

Table 1. Respondents' Job.

\begin{tabular}{|l|l|c|c|}
\hline No & \multicolumn{1}{|c|}{ Job } & Frequency & Percentage \\
\hline 1 & Civil servant & 11 & $20 \%$ \\
\hline 2 & $\begin{array}{l}\text { Private company } \\
\text { employee }\end{array}$ & 7 & $13 \%$ \\
\hline 3 & Entrepreneur & 12 & $22 \%$ \\
\hline 4 & $\begin{array}{l}\text { Only work at } \\
\text { BUMDes }\end{array}$ & 10 & $19 \%$ \\
\hline 5 & College student & 5 & $9 \%$ \\
\hline 6 & Others & 9 & $17 \%$ \\
\hline & Total & 54 & $100 \%$ \\
\hline
\end{tabular}

\subsection{Data analysis result}

Since the data used in this study is primary data using questionnaire, validity and reliability tests need to be conducted first. The result of the validity test shows loading factor 0.606 and the reliability test shows Cronbach's Alpha 0.711, which means the questionnaire is valid and reliable. The result of descriptive statistics is as shown in Table 4.2.

Table 4.2 Descriptive Statistics.

\begin{tabular}{|l|l|l|l|l|l|}
\hline Test & \multirow{2}{*}{$\begin{array}{l}\text { Descriptive } \\
\text { Statistics } \\
\text { (Mean; Std } \\
\text { Deviation) }\end{array}$} & \multicolumn{3}{|c|}{ Taired T-Test } \\
\cline { 3 - 6 } & & & & d & Sig.(2- \\
tailed)
\end{tabular}

The standard deviation is a reflection of the average deviation of the data from the mean. The standard deviation can describe how much the data varies. If the standard deviation value is greater than the mean value, it means that the mean value is a poor representation of the overall data. However, if the standard deviation value is smaller than the mean value, this indicates that the mean value can be used as a representation of the entire data. Based on Table 4.2, each variable has standard deviation which is smaller than its mean value. 
This indicates that the mean value can be used as a representation of the entire data.

The average sale before COVID-19 pandemic was at 3.278 while the average sale during COVID-19 pandemic was at 2.333, which means the sale has decreased during COVID-19 pandemic. The difference in sales before and during COVID-19 pandemic has a significant effect, with a $p$-value of 0.000 . This means that Hypothesis H1 is accepted, there is a significant difference between $B U M D e s$ sales before and during the COVID-19 pandemic. The results of this study are in line with Wojongan's (2021) research, where due to COVID-19 pandemic, the revenue target was extended from the previous target and even removed from the target. Previously, village income came from several business activities and showed income figures that were in line with expectation, but during the COVID-19 pandemic, it was necessary to diversify products to adapt to the needs of today's society.

The large-scale economic crisis due to COVID-19 has caused many activities to be reduced and even stopped. People's purchasing power has decreased and affecting MSMEs business continuity. MSMEs are the most type of enterprises in Indonesia and have also been proven to be resistant to various economic crises. But, during this COVID-19 pandemic, MSMEs are experiencing cash flow problems and weakening on the demand side which suppresses the sustainability of MSMEs. Product sales activities produced by various types of business activities are closely related to human purchasing power. When people's purchasing power decreases, it will certainly impact the company's total sales. When the company's sales decline, its profit will also decrease if the company is unable to minimize operating costs incurred [12].

BUMDes liquidity indicators are the BUMDes ability to pay debts and ability to pay BUMDes employees' salaries. BUMDes ability to pay payables shows a different means between before COVID-19 and during COVID-19 pandemic. The average value of BUMDes' ability to pay debts before COVID-19 was 3.000 while during COVID-19 pandemic was 2.889. The difference is not significant with the $p$-value is $>$ 0.05 , which is 0.254 .

As the second liquidity variable, BUMDes ability to pay salaries also does not show a significant difference between before and during COVID-19 pandemic. The average value of the ability of BUMDes to pay salaries before COVID-19 was 3.222, while during Covid, it was 3.194. The average difference was not significant where the p-value was 0.831. Based on the results, $\mathrm{H} 2$ and $\mathrm{H} 3$ cannot be accepted.

In theory, the financial performance of the industrial sector will certainly be affected by the economic crisis. This economic crisis will certainly cause a decline in sales in the industrial sector due to a decrease in purchasing power. If sales in the industrial sector experience a decline during the economic crisis due to the COVID-19 pandemic, this will certainly affect the company's financial condition in general, including the company's liquidity value. When current assets experience significant changes, this will ultimately affect the value of the liquidity ratio $[18,19]$. In line with the results of [21] research, the MSMEs had experienced problems in paying their employees' salaries during the COVID-19 pandemic. This happened because at the time there was no income due to the absence of demand from consumers. In order to reduce their operational burden, the MSMEs postponed the payment of employee salaries temporarily for one month.

Until now, all BUMDes in all Indonesian regions have received assistance from the government. The initial capital of BUMDes comes from village's investment to BUMDes which is allocated through the Village Revenue and Expenditure Budget (APB Desa). The Village Law which is clarified through the Regulation of the Minister of Villages PDTT Number 21 of 2015 concerning Priority Determination of the Use of Village Funds, states that one of the priorities for the use of village funds is the establishment and development of BUMDes. The existence of capital participation or investment from the village government has increased the cash amount received by BUMDes. Therefore, despite the decline in sales, BUMDes in Banda Aceh City are still able to pay their debts and their employees' salaries. Thus, there is no difference in BUMDes liquidity before and during COVID-19 pandemic.

\section{Conclusion}

Currently BUMDes face many problems due to COVID19 pandemic, especially the decreasing people's purchasing power. This decline in purchasing power has affected $B U M D e s$ in the city of Banda Aceh. There are several BUMDes in Banda Aceh that have closed their business activities because their sales have decreased drastically. In theory, when people's purchasing power decreases, it will certainly impact the company's total sales. When the company's sales decline, its profit will also decrease if the company is unable to minimize the operating costs. This analysis is based on the results of the paired sample t-test, where there is a significant difference in the number of sales between before and during COVID-19 pandemic.

The results of the different Paired sample t-test for the liquidity variable did not show a significant difference between before and during COVID-19 pandemic. BUMDes in the city of Banda Aceh are still able to pay their employee's salaries and are also still able to pay their business debts. This is most likely because BUMDes still receive some fund allocation from the village fund. The initial capital of BUMDes comes from village investment/capital participation which is allocated through the Village Revenue and Expenditure Budget (APB Desa). Hopefully, BUMDes will still receive fund allocation from APBDes funds, especially during crisis like COVID-19 pandemic.

\section{References}

1. H. Handi, Tujuh Provinsi dengan BUMDes Terbanyak, beritadaerah.co.id (2021) 
https:/www.beritadaerah.co.id/2021/06/30/tujuhprovinsi-dengan-bumdes-terbanyak/

2. Serambi Indonesia, Saatnya BUMDes Jadi Penggerak Ekonomi Desa (2019) https://aceh.tribunnews.com/2019/01/28/saatnyabumdes-jadi-penggerak-ekonomi-desa

3. S. R. Baker, N. Bloom, S. J. Davis, S. J. Terry, Covid-Induced Economic Uncertainty, NBER Working Paper No. 26983 (2020)

4. Ministry of Finance of the Republic of Indonesia, Minister of Finance Regulation Number 222/PMK.07/2020 concerning Village Fund Management (2020)

5. M. Shafi, J. Liu, W. Ren, Impact of COVID-19 Pandemic on Micro, Small, and Medium-sized Enterprises Operating in Pakistan, (2020)

6. A. V. E. Wojongan, Pengelolaan Badan Usaha Miliki Desa (BUMDes) di Tengah Pandemi COVID-19 (Studi di Desa Wiau Kecamatan Posumaen Kabupaten Minahasa Tenggara), Jurnal Politico Vol 10 No 4 (2021)

7. V. A. Rahmi, M. Z. Fathoni, H. Ismanto, Pendekatan Bisnis BUMDES Berkemajuan di Kondisi Wabah Pandemi COVID-19, Jurnal Riset Entrepreneurship Vol 3 No 2 (2020)

8. Handi, Tujuh Provinsi dengan BUMDes Terbanyak, beritadaerah.co.id (2021) https://www.beritadaerah.co.id/2021/06/30/tujuhprovinsi-dengan-bumdes-terbanyak/

9. OECD (Organisation for Economic Co-operation and Development), Coronavirus (COVID-19): SME Policy Responses (2020)

10. M. I. Modjo, Memetakan Jalan Penguatan Ekonomi Pasca Pandemi, The Indonesian Journal of Development Planning Vol IV No 2 (2020)

11. T. Ibn-Mohammed et al., A Critical Analysis of the Impacts of COVID-19 on the Global Economy and Ecosystem and Opportunities for Circular Economy Strategies, Resources, Conversation and Recycling Volume 164 (2020)

12. A. K. Pakpahan, COVID-19 dan Bagi Usaha Mikro, Kecil, dan Menengah, Jurnal Ilmiah Hubungan Internasional Edisi Khusus (2020)

13. D. R. Cahyani, 47 Persen UMKM Bangkrut Akibat Pandemi Corona, bisnis.tempo.co (2020) https://bisnis.tempo.co/read/1344540/47-persenumkm-bangkrut-akibat-pandemicorona/full\&view $=$ ok

14. A. A. Istiningrum, Perbandingan Kinerja Keuangan Perusahaan Jasa yang Terdaftar di BEJ Sebelum dan Selama Krisis Moneter, Jurnal Pendidikan Akuntansi Indonesia Vol. IV No. 1 (2005)

15. I. Rofikoh, Pengaruh Krisis Moneter Terhadap Kinerja Perusahaan Publik di Bursa Efek Jakarta, Journal of Accounting and Investment Vol 2 No 2 (2001)

16. H. Shen et al., The Impact of the COVID-19 Pandemic on Firm Performance, Emerging Markets Finance and Trade Vol 56 Issue 10 (2020)

17. C. I. Burhanuddin, M. N. Abdi, Ancaman Krisis Ekonomi Global dari Dampak Penyebaran Virus Corona (COVID-19). Jurnal AkMen, 17(1) (2020)
18. S. Devi et al., The Impact of COVID-19 Pandemic on the Financial Performance of Firms on the Indonesia Stoch Exchange, Journal of Economics, Business, and Accountancy Ventura Vol. 23 No. 2 (2020)

19. C. Wijayangka, Analisis Kinerja Keuangan Perusahaan Sektor Manufaktur Akibat Krisis Keuangan Amerika. Jurnal Manajemen Indonesia, 14(2) (2014)

20. F. M. Bintang, A. Malikah, Afifudin, Pengaruh Opini Audit Tahun Sebelumnya, Debt Default, Rasio Likuiditas, Rasio Leverage Terhadap Opini Audit Going Concern. E-JRA 8(10) (2019)

21. R. N. Sari, Dampak Pandemi COVID-19 Terhadap UMKM Batik di Kabupaten Sumenep, RISTANSI: Riset Akuntansi, 1(1) (2020)

22. J. F. Hair et al., Multivariate Data Analysis, Prentice-Hall Inc, New Jersey (2010) 